\title{
Chemical and Biological Evaluation of Essential Oils with Economic Value from Lauraceae Species
}

\author{
Jefferson R. de A. Silva, ${ }^{*, a}$ Dominique F. M. do Carmo, ${ }^{a}$ Érika M. Reis, ${ }^{a}$ Gérzia M. C. Machado, ${ }^{b}$ \\ Leonor L. Leon, ${ }^{b}$ Bianca O. da Silva, ${ }^{c}$ José Luiz P. Ferreira ${ }^{c, d}$ and Ana Claudia F. Amaral ${ }^{c}$
}

${ }^{a}$ Departamento de Química, Universidade Federal do Amazonas, 69077-000 Manaus- AM, Brazil

${ }^{b}$ Departamento de Imunologia, Fundação Oswaldo Cruz, 21040-360 Rio de Janeiro-RJ, Brazil

${ }^{c}$ Laboratório de Plantas Medicinais e Derivados, Fundação Oswaldo Cruz, 21041-250 Rio de Janeiro-RJ, Brazil

${ }^{d}$ Faculdade de Farmácia, Universidade Federal Fluminense, 2421-000 Niterói-RJ, Brazil

Este trabalho compara pela primeira vez a composição química do óleo essencial das folhas de Licaria canella coletadas em duas estações climáticas. Os resultados foram comparados com os obtidos para o óleo essencial das folhas de outra espécie da família Lauraceae, Aniba canelilla, coletada no mesmo período. Ambos os óleos essenciais foram analisados por CG-DIC e CG-EM, e os resultados indicaram uma grande quantidade de benzenóides, sendo o principal constituinte em L. canella o benzoato de benzila e para A. canelilla, o 1-nitro-2-feniletano. A comparação das atividades biológicas mostrou que o óleo de L. canella $\left(\mathrm{IC}_{50} 19 \mu \mathrm{g} \mathrm{mL}^{-1}\right)$ foi mais ativo contra as cepas de Leishmania amazonensis e menos citotóxico em cultura de macrófagos do que o de $A$. canelilla $\left(\mathrm{IC}_{50} 40 \mu \mathrm{g} \mathrm{mL} \mathrm{mL}^{-1}\right)$. Por outro lado, o óleo de L. canella exibiu uma maior citotoxicidade contra Artemia salina com uma concentração letal $\left(\mathrm{CL}_{50}\right)$ igual a $5,25 \mu \mathrm{g} \mathrm{mL^{-1 }}$.

This work compares the chemical composition of the essential oils from the leaves of Licaria canella collected in two different seasons. The results of this investigation were compared with the leaf essential oils of other species of the Lauraceae family, Aniba canelilla, collected at the same time. Both essential oils were analyzed by GC-FID and GC-MS. The results demonstrated a larger predominance of benzenoids, being the main constituent benzyl benzoate for L canella and 1-nitro-2-phenylethane for A. canelilla. The comparison of the biological activities showed that $L$. canella $\left(\mathrm{IC}_{50} 19 \mu \mathrm{g} \mathrm{mL}^{-1}\right.$ ) was more active against Leishmania amazonensis strains and less cytotoxic in macrophage cultures than A. canelilla ( $\mathrm{IC}_{50} 40 \mu \mathrm{g} \mathrm{mL}^{-1}$ ). On the other hand, the L. canella oil displayed a higher cytotoxicity against Artemia salina with a lethal concentration

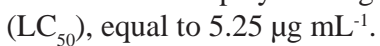

Keywords: Licaria canella, Aniba canelilla, essential oil, Leishmania amazonensis, cytotoxicity

\section{Introduction}

The Lauraceae family contains about 50 genera and approximately 2500-3500 species distributed in tropical to subtropical areas, with a few occurrences in temperate regions and is among those with the greatest number of specimens in different regions of the Amazon. ${ }^{1}$ Twentytwo genera are found in Brazil, distributed in rain forests as well as in restingas and cerrados. ${ }^{2}$ The floristic mapping held in the Adolpho Ducke Reserve (Amazonas

*e-mail: jrocha_01@ufam.edu.br
State, Brazil) cataloged so far 13 genera and 99 species. $^{3}$ Most of the family members are characterized by a woody habit and are of great economic importance worldwide, as they provide valuable timber, aromatic oils and important substances that are widely employed in the pharmaceutical and food industries, with emphasis on the genera Aniba, Licaria, Nectandra, Ocotea. In the Amazonian region these genera are popularly known as "pau-rosa" (rosewood) and "louros". The oil of "pau-rosa" (Aniba rosaeodora Ducke) has historical importance. It has already emerged in the third position in the exports lines of the Amazonian region, behind 
only rubber and chestnut, that rank first and second, respectively. ${ }^{4}$ Licaria canella (Meissner) Kostermans is a botanical species popularly known as "louro-pirarucu". Within the ethnic group Tacana of the Amazonian region, this species has the same name and use as Aniba canelilla (H.B.K.) Mez, probably due to their aromatic barks. ${ }^{5}$ The barks of both species have ethnopharmacological use to alleviate abdominal pain, intestinal cramps or discomfort, without diarrhea. ${ }^{6}$ Phytochemical studies of the trunk wood of L. canella described the presence of dillapiol, elemicin and the neolignans canellins A-C. ${ }^{7}$ The ethanol extract of the bark of this species showed activity in vitro against chloroquine sensitive Plasmodium falciparum $\left(\mathrm{IC}_{50}=3.8 \mu \mathrm{g} \mathrm{mL} \mathrm{L}^{-1}\right.$ ) and also resistant strains $\left(\mathrm{IC}_{50}=3.2 \mu \mathrm{g} \mathrm{mL}-1{ }^{-1}\right){ }^{6}$ The extract of the stem demonstrated low activity against RPMI 8226 cancer cells. ${ }^{8}$

Aniba canelilla, known as "casca-preciosa" (precious bark), was the target of an ancestral confusion in the search for the "country of cinnamon". ${ }^{9}$ The cinnamon flavor was responsible for the confusion between A. canelilla and the Cinnamomum species. In the case of the bark of C. zeylanicum Blume, the major principle of cinnamon odor is cinnamic aldehyde, ${ }^{10}$ while in A. canelilla, it is the 1-nitro-2-phenylethane. ${ }^{11}$ Previous works on A. canelilla described the isolation of benzyltetrahydroisoquinoline alkaloids from the stem bark. ${ }^{12}$ The chemical compositions of the essential oils and hexane extract from the leaves and stem bark were identified by spectroscopic methods. ${ }^{13,14}$ Crude extracts of the stem bark from A. canelilla were active at $100 \mu \mathrm{g} \mathrm{mL}^{-1}$ in vitro against Leishmania spp. and Trypanosoma cruzi. ${ }^{15}$ The bark oil of this species showed cardiovascular effects in normotensive rats. ${ }^{16} \mathrm{~A}$ higher antioxidant activity using DPPH radical scavenging $\left(\mathrm{EC}_{50}=4.41 \mu \mathrm{g} \mathrm{mL}^{-1}\right)$ was reported for methanol extracts of the wood. The brine shrimp bioassay performed with the trunk oils of A. canelilla $\left(\mathrm{LC}_{50}=21.61 \mu \mathrm{g} \mathrm{mL}^{-1}\right)$ showed cytotoxicity higher than the wood extracts $\left(\mathrm{LC}_{50}=91.38 \mu \mathrm{g} \mathrm{mL} \mathrm{mL}^{-1}\right) .{ }^{17}$ 1-Nitro-2-phenylethane produced antinociceptive effects but its mechanism of action was not elucidated. ${ }^{18}$

This report presents the chemical composition of the essential oils of $L$. canella and relates it to the oil of $A$. canelilla, collected in two different seasons. The emergence of parasite resistance to current therapies highlights the importance of essential oils as novel antiparasitic agents. In this context, the oils collected in October 2007 were tested in vitro on promastigote forms of Leishmania amazonensis. Additionally, toxicity evaluation of these oils with nonparasite macrophages and brine shrimp (Artemia salina) were performed.

\section{Experimental}

\section{Plant Material}

The leaves of $L$. canella and A. canelilla were collected from four individuals at the Adolpho Ducke Reserve, near the city of Manaus, Amazonas state, Brazil. Voucher specimens were deposited in the Herbarium of INPA (Amazonas state) under numbers 226360 and 220094, respectively. These species were collected in the dry (October 2007) and rainy seasons (February 2008). Flowers were observed in February, without fruits in either month. Data of pluviometric precipitation were obtained at the site of the National Institute of Meteorology and these maps showed no atypical differences in these seasons. ${ }^{19}$

\section{Extraction of essential oil}

The leaves collected from L. canella and A. canelilla $(600 \mathrm{~g})$ were dried at room temperature for 3 days, minced and submitted to hydrodistillation for $4 \mathrm{~h}$ in a Clevengertype apparatus.

\section{Essential oil analysis}

The identification of compounds was performed by comparison of their retention indices and mass spectra with those reported in the literature or stored in the Wiley data system library. ${ }^{20,21}$ The retention indices were calculated for all volatile constituents using $n$-alkane homologous series. GC analyses were performed using a HP 5890 gas chromatograph equipped with a DB-5 capillary column $(30 \mathrm{~m} \times 0.25 \mathrm{~mm}$, film thickness $0.25 \mu \mathrm{m})$ and a FID detector. The oven temperature was programmed from $60{ }^{\circ} \mathrm{C}$ to $290{ }^{\circ} \mathrm{C}$ at a rate of $3{ }^{\circ} \mathrm{C} \mathrm{min}-1$, then isothermal at $290^{\circ} \mathrm{C}$ for $10 \mathrm{~min}$, using $\mathrm{H}_{2}$ as the carrier gas $\left(1.0 \mathrm{~mL} \mathrm{~min}^{-1}\right)$. Injector and detector temperatures were $230^{\circ} \mathrm{C}$ and $280^{\circ} \mathrm{C}$, respectively.

GC-MS analyses were performed using a HP 6890 gas chromatograph interfaced with a HP 5873 Mass Selective Detector (ionization voltage $70 \mathrm{eV}$ ), equipped with a DB-5MS capillary column $(30 \mathrm{~m} \times 0.25 \mathrm{~mm}$, film thickness $0.25 \mu \mathrm{m})$, using $\mathrm{He}$ as the carrier gas $\left(1.0 \mathrm{~mL} \mathrm{~min}^{-1}\right)$. Oven and injector temperatures were as described before.

\section{In vitro antileishmanial assay}

Promastigotes of Leishmania amazonensis strains MHOM/BR/77LTB0016, isolated from patients with cutaneous leishmaniasis in Manaus, were routinely cultured at $26{ }^{\circ} \mathrm{C}$ in Schneider's medium supplemented 
with $10 \%$ fetal calf serum (FCS), pH 7.2. Parasites were harvested from the medium on day 4 , when a high percentage of infective forms (metacyclic promatigotes) were found. After being harvested, the parasites were counted in a Neubauer's chamber and adjusted to a concentration of $4 \times 10^{6}$ promastigotes $\mathrm{mL}^{-1}$ using the supernatant of each culture as diluent. The samples were dissolved in DMSO (the highest concentration was 1.4\%, which was not hazardous to the parasites) and added to parasite suspensions in final concentrations between 0.156 to $320 \mu \mathrm{g} \mathrm{mL}^{-1}$. After $24 \mathrm{~h}$ of incubation, the parasites were counted and compared to the controls, containing only DMSO and parasites. Pentamidine isethionate was used as the reference drug. The sample concentration corresponding to $50 \%$ of parasite growth inhibition was expressed as the $\mathrm{IC}_{50}$.

\section{Cytotoxicity assay}

In order to evaluate the toxicity of the sample for the host cell, mice peritoneal macrophages were isolated in RPMI 1640 medium (Sigma Cell Culture, St. Louis, MO, USA), containing $200 \mathrm{UI} \mathrm{mL}^{-1}$ penicillin, $200 \mu \mathrm{g} \mathrm{mL}^{-1}$ of streptomycin, $1 \mathrm{mmol} \mathrm{L}^{-1}$ sodium piruvate, $1 \mathrm{mmol} \mathrm{L}^{-1}$ of L-glutamine and $1 \mathrm{~mol} \mathrm{~L}^{-1}$ HEPES buffer (Sigma Cell Culture, St. Louis, MO, USA). Cells were counted in a Neubauer's chamber using Erythrosine B as vital dye (Sigma Cell Culture, St. Louis, MO, U.S.A.) and adjusted to a concentration of $4 \times 10^{6} \mathrm{~mL}^{-1}$. After that, the cells were cultured in a 96 well culture plate (Falcon, New Jersey, U.S.A.), at $37{ }^{\circ} \mathrm{C}$ and in an atmosphere of $5 \% \mathrm{CO}_{2}$. The sample was added to the medium in a concentration equivalent to $\mathrm{IC}_{50}$ and $2 \times \mathrm{IC}_{50}$ of the in vitro activity assay from $L$. amazonensis species. The sample and pentamidine isethionate (reference drug) were added to the cultures and after 24 hours the viability of treated cells were compared to the control without drugs, through the MTT methodology. 22,23

\section{Toxicity testing against brine shrimp}

The brine shrimp (Artemia salina) lethality test was performed by the method of Meyer et al. ${ }^{24}$ with some modifications. The samples were dissolved in dimethylsulfoxide (DMSO) and diluted serially in seawater. In each case three replicates of each concentration were assayed. Survivors were counted after $24 \mathrm{~h}$ and the $\mathrm{LC}_{50}$ values in $\mu \mathrm{g} \mathrm{mL}{ }^{-1}$ were determined by Probit analysis. ${ }^{25}$ Saline solution with DMSO was used as negative control $\left(\mathrm{LC}_{50}>1000 \mu \mathrm{g} \mathrm{mL}^{-1}\right)$, while lapachol was used as a positive control $\left(\mathrm{LC}_{50}=23.0 \mu \mathrm{g} \mathrm{mL}^{-1}\right)$.

\section{Results and Discussion}

The yield of the oils was $1.2 \%$ (October, dry season) and $1.3 \%$ (February, rainy season) for L. canella leaves. The extraction resulting from A. canelilla leaves was $0.8 \%$ (October) and $0.9 \%$ (February). As shown in Table 1, compounds of the essential oils of L. canella and A. canelilla were identified by GC-FID and GC-MS analyses.

The results showed that the essential oils of these species were rich in benzenoid compounds, with minor constituents represented by mono and sesquiterpenoids (Table 2).

The major constituent of the leaf essential oils from L. canella (October 2007, 69.7\% and February 2008, $73.0 \%$ ) was benzyl benzoate. For A. canelilla it was 1-nitro2-phenylethane (October 2007, 88.9\% and February 2008, $88.5 \%)$. The percent content of this last compound, which was recently isolated and identified by NMR spectral data, ${ }^{17}$ is in agreement with previous studies published on this species collected in the rainy season. ${ }^{26}$ On the other hand, in contrast with the results described for the species collected in the State of Pará, ${ }^{26}$ the collection related to the dry season (October 2007) did not show a significant difference in its content of 1-nitro-2-phenylethane when compared to the rainy season. Additionally, the presence of methyleugenol, a component considered as a marker of the oils from Pará State, ${ }^{26}$ was not identified in the analyses of the essential oils of A. canelilla found in Amazon State. The qualitative comparison and the percent content of the oils from the two collections showed similarity, $(E)$ caryophyllene being the second most abundant constituent in both collections. With respect to the essential oils from the leaves of $L$. canella, there is no report on the description of its chemical composition, which presented almost the same profile in both extractions, with benzyl benzoate being the main constituent. The other more abundant constituents were: $\alpha$-pinene, $\alpha$-phellandrene, $\alpha$-copaene and $(E)$ caryophyllene. $p$-cymene, $\delta$-3-carene and 1,8-cineol were detected only in the essential oils of the rainy season. The percent differences are listed in Table 1.

The evaluation of the antileishmanial activity of the essential oils (October 2007) of L. canella $\left(\mathrm{IC}_{50}=19 \mu \mathrm{g} \mathrm{mL}-1\right)$, and A. canelilla $\left(\mathrm{IC}_{50}=40 \mu \mathrm{g} \mathrm{mL}^{-1}\right)$ indicate moderate activity against $L$. amazonensis promastigotes. These essential oils presented low cytotoxicity on uninfected peritoneal macrophages, even when evaluated in amounts twice as large as their $\mathrm{IC}_{50}$ and comparable to the reference drug (pentamidine) (Table 3). These results are relevant due to the low toxicity presented by the oils when compared to the high toxicity of the therapeutic drugs used to treat the disease. ${ }^{27}$ 
Table 1. Chemical composition of the leaf essential oils of L. canella and A. canelilla

Oil composition / (\%)

\begin{tabular}{|c|c|c|c|c|c|}
\hline \multirow[t]{2}{*}{ Compounds } & \multirow[t]{2}{*}{ RI } & \multicolumn{2}{|c|}{ L. canella } & \multicolumn{2}{|c|}{ A. canelilla } \\
\hline & & October & February & October & February \\
\hline$\alpha$-thujene & 930 & 0.17 & 0.15 & - & - \\
\hline$\alpha$-pinene & 939 & 3.54 & 3.05 & 0.75 & 0.61 \\
\hline camphene & 954 & 1.54 & 1.41 & - & - \\
\hline$\beta$-pinene & 982 & 1.35 & 1.31 & 0.43 & 0.46 \\
\hline$\beta$-myrcene & 991 & 0.35 & 0.45 & - & - \\
\hline$\alpha$-phellandrene & 1003 & 4.20 & 3.33 & - & - \\
\hline$\delta$-3-carene & 1010 & - & 1.60 & - & - \\
\hline p-cymene & 1025 & - & 0.26 & - & - \\
\hline$\beta$-phellandrene & 1030 & - & - & 0.80 & 1.14 \\
\hline benzyl alcohol & 1032 & 0.34 & $\operatorname{Tr}$ & - & - \\
\hline 1,8-cineol & 1033 & - & 0.19 & - & - \\
\hline (E )- $\beta$-ocimene & 1048 & $\operatorname{tr}$ & $\operatorname{Tr}$ & - & - \\
\hline$\gamma$-terpinene & 1061 & $\operatorname{tr}$ & $\operatorname{Tr}$ & - & - \\
\hline$\alpha$-terpinolene & 1088 & 0.39 & 0.30 & - & - \\
\hline linalool & 1097 & - & - & 0.23 & 0.23 \\
\hline borneol & 1164 & 0.48 & 0.47 & - & - \\
\hline terpin-4-ol & 1175 & $\operatorname{tr}$ & $\operatorname{Tr}$ & - & - \\
\hline$\alpha$-terpineol & 1189 & - & - & 0.23 & 0.29 \\
\hline trans-cinnamaldehyde & 1266 & $\operatorname{tr}$ & 0.78 & - & - \\
\hline bicycloelemene & 1282 & 0.83 & 0.19 & - & - \\
\hline 1-nitro-2-phenylethane & 1327 & - & - & 88.9 & 88.5 \\
\hline eugenol & 1356 & 0.42 & 0.28 & 0.17 & 0.08 \\
\hline$\alpha$-cubebene & 1378 & 0.27 & 0.11 & - & - \\
\hline$\alpha$-copaene & 1380 & 4.99 & 4.51 & 0.71 & 0.71 \\
\hline$\beta$-cubebene & 1390 & 0.60 & 0.46 & - & - \\
\hline (Z)-caryophyllene & 1405 & - & - & 0.30 & 0.27 \\
\hline (E)-caryophyllene & 1424 & 3.01 & 3.02 & 4.21 & 5.04 \\
\hline trans-cinnamylacetate & 1443 & 0.81 & 0.83 & - & - \\
\hline$\alpha$-humulene & 1454 & 0.79 & 0.71 & 0.46 & 0.64 \\
\hline epi-bicyclosesquiphellandrene & 1489 & 0.12 & - & - & - \\
\hline bicyclogermacrene & 1494 & 0.85 & 1.54 & - & - \\
\hline$\beta$-bisabolene & 1508 & - & - & 0.49 & 0.64 \\
\hline$\delta$-cadinene & 1528 & 0.37 & 0.22 & 0.14 & 0.20 \\
\hline cadina-1,4-diene & 1529 & 0.10 & - & - & - \\
\hline spathulenol & 1578 & 0.11 & - & - & - \\
\hline caryophyllene oxide & 1581 & - & - & 0.14 & 0.91 \\
\hline germacrene D & 1584 & 0.26 & 0.28 & - & - \\
\hline benzyl benzoate & 1762 & 69.7 & 73.0 & 0.21 & 0.19 \\
\hline Identified components / (\%) & & 95.6 & 98.7 & 98.1 & 99.9 \\
\hline
\end{tabular}

tr: traces $(<0.1 \%)$. 
Table 2. The chemical class distribution of the essential oils of L. canella and A. canelilla

\begin{tabular}{lcccc}
\hline \multirow{2}{*}{$\begin{array}{l}\text { Compound } \\
\text { class }\end{array}$} & \multicolumn{2}{c}{ L. canella / (\%) } & \multicolumn{2}{c}{ A. canelilla / (\%) } \\
\hline Monoterpenoids & 12.0 & 12.5 & 2.4 & 2.7 \\
Sesquiterpenoids & 12.3 & 11.2 & 6.4 & 8.4 \\
Benzenoids & 71.3 & 74.9 & 89.3 & 88.8 \\
\hline
\end{tabular}

Table 3. In vitro activity of essential oils of $L$. canella and A. canelilla against $L$. amazonensis and macrophages

\begin{tabular}{lccc}
\hline \multirow{2}{*}{$\begin{array}{lc}\mathrm{IC}_{50} /\left(\mu \mathrm{g} \mathrm{mL}^{-1}\right) \\
\text { L. amazonensis }\end{array}$} & \multicolumn{2}{c}{ Cytotoxicity / (\%) } \\
\hline L. canella & $19.0 \pm 0.9$ & $\mathrm{IC}_{50}$ & 6.2 \\
& $40.0 \pm 1.2$ & $\left(2 \times \mathrm{IC}_{50}\right)$ & 15.1 \\
$\begin{array}{l}\text { A. canellila } \\
\mathrm{IC}_{50}\end{array}$ & 9.3 \\
$\begin{array}{l}\text { Pentamidine } \\
\text { (reference drug) }\end{array}$ & $4.8 \pm 0.1$ & $\left(2 \times \mathrm{IC}_{50}\right)$ & 16.0 \\
\hline
\end{tabular}

In this context, the results obtained in the evaluation with Artemia salina indicated high cytotoxicity for L. canella, with a lethal concentration $\left(\mathrm{LC}_{50}\right.$ ) equal to $5.25 \mu \mathrm{g} \mathrm{mL} \mathrm{mL}^{-1}$, while in the case of $A$. canelilla, the $\mathrm{LC}_{50}$ observed was about 13 times greater $\left(68.37 \mu \mathrm{g} \mathrm{mL}^{-1}\right)$, being thus in agreement with the greater activity against $L$. amazonensis strains found for the oils of L. canella.

\section{Conclusions}

The main constituent of the essential oils of $L$. canella is commercially used as a topical medication against several parasitoses, which suggests a potential use of this oil for this purpose. The leaves of L. canella and A. canelilla may be qualified as two natural, abundant and ecologically renewable sources of benzyl benzoate and 1-nitro-2-phenylethane, respectively, with commercial value for to medicinal purposes in the case of L. canella $^{28,29}$ and as an aroma for the cosmetic and food industries regarding A. canelilla.

\section{Acknowledgments}

The authors are grateful for the financial support provided by CNPq and by the FAPEAM / PIPT Program and thank Ms. June Justa for revising the manuscript.

\section{References}

1. Eklund, H.; Bot. J. Linn. Soc. 2000, 132, 397.

2. Quinet, A.; Acta Bot. Bras. 2005, 19, 563.

3. Ribeiro, J. E. L. S.; Hopkins, M. J. G.; Vicentini, A.; Sothers, C. A.; Costa, M. A. S.; Brito, J. M.; Souza, M. A. D.; Martins, L. H. P.; Lohmann, L. G.; Assunção, P. A. C. L.; Pereira, E. C.; Silva, C. F.; Mesquita, M. R.; Procópio, L. C.; Flora da Reserva Ducke. Guia de Identificação das Plantas Vasculares de uma Floresta de Terra-Firme na Amazônia Central, INPA, DFID: Manaus, AM, Brasil, 1999.

4. Marques, C. A.; Floresta e Ambiente 2001, 8, 195.

5. Hocking, G. M.; A Dictionary of Natural Products. Terms in the Field of Pharmacognosy Relating to Natural Medicinal and Pharmaceutical Materials and the Plants, Animals, and Minerals from which they are Derived, $2^{\text {nd }}$ ed., Plexus Publishing: Medforf, 1997, p. 992.

6. Deharo, E.; Bourdy, G.; Quenevo, C.; Muñoz, V.; Ruiz, G.; Sauvain, M.; J. Ethnopharmacol. 2001, 77, 91.

7. Giesbrecht, A. M.; Franca, N. C.; Gottlieb, O. R.; Rocha, A. I.; Phytochemistry 1974, 13, 2285.

8. Suffredini, I. B.; Paciencia, M. L. B.; Varella, A. D.; Younes, R. N.; Fitoterapia 2007, 78, 223.

9. Pinto, A. C.; Quim. Nova 1995, 18, 608.

10. Senanayake, U. M.; Lee, T. H.; Wills, R. B. H.; J. Agric. Food Chem. 1978, 26, 822.

11. Gottlieb, O. R.; Magalhães, M. T.; J. Org. Chem. 1959, 24, 2070.

12. Oger, J. M.; Fardeau, A.; Richomme, P.; Fournet, A.; Guinaudeau, H.; Can. J. Chem. 1993, 71, 1128.

13. Lima, M. P.; Silva, T. M. D.; Silva, J. D.; Zoghbi, M. G. B.; Andrade, E. H. A.; Acta Amaz. 2004, 34, 329.

14. Oger, J. M.; Richomme, P.; Guinaudeau, H.; Bouchara, J. P.; Fournet, A. ; J. Essent. Oil Res. 1994, 6, 493.

15. Fournet, A.; Barrios, A. A.; Muñoz, V.; J. Ethnopharmacol. 1994, 41, 19.

16. Lahlou, S.; Magalhães, P. J. C.; Siqueira, R. J. B.; Figueiredo, A. F.; Interaminense, L. F. L.; Maia, J. G. S.; Sousa, P. J. C.; J. Cardiovasc. Pharmacol. 2005, 46, 412.

17. Silva, J. K. R.; Sousa, P. J. C.; Andrade, E. H. A.; Maia, J. G. S.; J. Agric. Food Chem. 2007, 55, 9422.

18. Lima, A. B.; Santana, M. B.; Cardoso, A. S.; Silva, J. K. R.; Maia, J. G. S.; Carvalho, J. C. T.; Sousa, P. J. C.; Phytomedicine 2009, 16, 555.

19. http://reia.inmet.gov.br/html/clima.php?lnk=/conab/climatologia/ dimap/selecao_spi_X.php, accessed in January 2009.

20. Adams R. P.; Identification of Essential oil Components by Gas Chromatography/Quadrupole Mass Spectroscopy, Allured Publishing Corp.: Carol Stream, IL, 2001.

21. Lin, L.-Y; Peng, C.-C; Liang, Y.-J; Yeh, W.-T; Wang, H.-E; Yu, T.-H.; J. Agric. Food Chem. 2008, 56, 4435. 
22. Mosmann, T.; J. Immunol. Methods 1983, 65, 55.

23. Ferrari, M.; Fornasiero, M. C.; Isetta, A. M.; J. Immunol. Methods 1990, 131, 165.

24. Meyer, B. N.; Ferrigni, N. R.; Putnam, J. E.; Jacobsen, L. B.; Nichols, D. E.; McLaughlin, J. L.; Planta Med. 1982, 45, 31.

25. Finney, D. J.; Probit Analysis, $3^{\text {rd }}$ ed., Cambridge University Press: Cambridge, 1971.

26. Taveira, F. S. N.; de Lima, W. N.; Andrade, E. H. A.; Maia, J. G. S.; Biochem. Syst. Ecol. 2003, 31, 69.
27. Amato Neto, V.; Tuon, F. F.; Bacha, H. A.; Neto, V. A.; Nicodemo, A. C.; Acta Tropica 2008, 105, 1.

28. Oladimeji, F. A.; Orafidiya, O. O.; Ogunniyi, T. A. B.; Adewunmi, T. A.; Onayemi, O.; Int. J. Aromather. 2005, 15, 87.

29. Oladimeji, F. A.; Orafidiya, L. O.; Ogunniyi, T. A. B.; Adewunmi, T. A.; J. Ethnopharmacol. 2000, 72, 305.

Received: January 31, 2009 Web Release Date: June 18, 2009 